\section{Ignition and Growth of Fire}

In this Section physical aspects of combustion and heat transfer are studied. Techniques involving the use of models are being developed to determine the factors-particularly wind, ventilation, fuel, and shape and size of compartment-which control the growth of fire and its spread within and between buildings. The aim of this work is to provide a scientific basis for the fire grading and adequate separation of buildings. Ten laboratories in other countries are also co-operating on an agreed programme of experiments with models. The results of this international programme should lead to theorotical understanding of the progress of fires in buildings.

Further work is being carried out on the development of fires in the open, as this will have application both to forest fires and fires in built-up areas.

\section{Building Materials and Structures}

Since much of the total damage by fire occurs in buildings, this Section studies building materials under fire conditions to obtain basic data for the design and protection of structures which will help to control the development and spread of fire. It also performs, at the request of manufacturers, many tests on structural elements, and spread-of-flame tests on building materials. Its work is being used in the revision of building by-laws, and in the advice given to architects, builders, structural engineers and local authorities on appropriate types of structure and materials.

\section{Chemistry and Chemical Engineering}

This Section is concerned with industrial fires and explosions involving gases, vapours, dusts and unstable materials not classified as explosives. Working in close co-operation with the Factory Inspectorate of the Ministry of Labour, its aim is to assess hazards and devise precautionary measures. In collaboration with the Extinguishing Materials and Equipment Section, studies are made of the means of extinguishing fires in fiammable liquids, the use of vapour phase inhibiting agents and the possibility of extinguishing fires in buildings by filling the interior with inert gas. Experiments with inert atmospheres are now being carried out with a specially adapted jet engine.

\section{Extinguishing Materials and Equipment}

The main purpose of this Section is to study the properties of, and methods of applying, extinguishing agents, for example, water, foam and dry powder. Models of rooms and buildings are used to learn more about the various mechanisms by which water puts out fires. This Section studies the automatic detection of fires and the performance of detection systems. It carries out tests-many of them for the Fire Offices' Committeo-on equipment, including automatic sprinkler systems, portable fire-extinguishing appliances, and automatic fire alarms. In co-operation with official bodies and manufacturers, the Section assists in drawing up standards and specifications for such equipment.

In addition, the Fire Research Station has a library which provides an extensive coverage of fire literature as well as information and intelligence services.

\title{
FUTURE OF THE GENERAL DEGREE IN BRITISH UNIVERSITIES
}

$\mathrm{D}^{\mathrm{r}}$ ISCUSSIONS at the Home Universities Conference are not required to reach agreed conclusions. Had this been the case, the discussion on the "Future of the General Degree" during the recent Conference of the Universities of the United Kingdom, held in London during December 9-10, would prob. ably have reached the conclusion that it is a good degree, but that it may have no future.

There were two opening speeches. The first was given by Mr. D. W. Reece, lecturer in humanity at the University of Aberdeen, who argued that the planned increase of student numbers to 170,000 , which will bring the proportion of students to total population in England to the same figure as it now is in Scotland, must (since there are no grounds to suppose that the English are more intelligent than the Scots) lead to the entry of a large number of students of lower calibre than hitherto, who will need easier courses of instruction. He assumed that the general degree in England can be equated to the ordinary degree in Scotland, and that there will be an increasing need for it, as providing a suitable education for the less-able student.

The second opening speech, given by Prof. F. C. Frank (professor of physies, University of Bristol), dealt with the general degree with honours provided by most of the English universities, and in particular with the general degree of B.Sc. He took the opportunity to direct attention to the appalling complexity and disparity of terminology employed by various universities in describing the courses they offer. But while the general honours degrees are of various structure from university to university, broadly speaking they differ from special honours degrees mainly in the third year of study, which in a special degree is devoted to a single subject, whereas it still covers two or more subjects in a general degree.

The distinction between the special and the general degree ought not, Prof. Frank said, to be regarded as one of merit. He gave it as his considered judgment that in practice it is harder to get a first class in the general than in the special degree, though easier to get a poor second or a third class. It is judged to be a suitable career education for school-teaching, a course of education suited to the type of mind which is less happy concentrating on a narrow front, and a more balanced course for those whose intended future is a non-academic one (whereas the more academic will yet have time to take up their various academic subjects in turn). In short, he considered it a suitable education for a Cabinet Minister.

Judging from newspaper reports of the discuasion, it is probably the former conception of the general degree which appears more realistic outside university circles. This view was not without support at the Conference, but most speakers concerned themselves with the general honours degree : its merit was confirmed, but its name was brought in question. The 
outstanding argument which can be made against the type of education given in a general degree was not brought into the discussion. This is Dr. C. R. Burch's principle, the broadening effect of specialization-if one studies chemistry, for example, superficially, it is chemistry only; the deeper one studies it, the more one is forced to discover its connexions with other subjects.

In the view of the University of Southampton, expressed by Prof. H. C. Baldry (classics), the general honours degree, under that title, has no future at all. It carries from the past (meaning, for Southampton, the period when it was under the tutelage of London) what according to this view is an indelible association with mediocrity. Southampton, in its regulations governing admissions since 1959, has abolished the general degree, but at the same time has provided a flexibility in the make-up of the course for an honours B.Sc. so that it is possible for it to be essentially similar to one of the less-wide general B.Sc. degrees, such as that provided at Bristol. Prof. G. Gee (Sir Samuel Hall professor of chemistry, University of Manchester), supporting the view that the choice between specialization and a wider curriculum is quite distinct from the need to provide courses at different intellectual levels, advocated a single B.Sc. certificate, with the appropriate class of honours, and the sub. jects studied, and for what periods, separately recorded on the certificate.

Against this view we have the policy, implied by the latest University of London regulations, and made explicit by Prof. J. G. Semple (professor of mathe- matics, King's College), that the general degree serves a dual purpose, being in its honours classes fully equal, and perhaps in the first class a shade superior, to the special degree, but in its pass category offering an easier route to a degree for the less-able student.

This is indeed how it tends to work out in practice, but it is a matter for urgent decision whether this dual purpose use is compatible with a proper recognition of the status of a good general honours degree. Prof. Frank, in his reply, considered that this was only possible if one made a strictly parallel division into general honours, general ordinary, special honours and special ordinary, even though ordinary specialists are the type of graduate which universities are least desirous of producing.

A distinct but important subject was brought into the discussion by Prof. W. F. W. Wynne-Jones (professor of chemistry, King's College, Newcastle on Tyne), namely, the danger that a general honours student may be nobodv's baby. He suggested that interdepartmental professors-professors without portfolio-could take responsibility for these students, and Prof. Frank in his reply remarked that such interdepartmental professorships are being increasingly established in the United States, mainly to provide liaison between departments at the researchlevel. It was interesting to see in Prof. Wynne-Jones's proposal the way in which such interdepartmental professors could be given the opportunity to involve themselves with undergraduates.

F. C. FranK

\section{THE UNIVERSITY GRANTS COMMITTEE}

\section{ANNUAL REPORT}

$\mathrm{T}$ HE annual returns from universities and colleges in Great Britain in receipt of Treasury grants for the academic year 1958-59, now covering 21 universities and 3 colleges, issued by the University Grants Committee, is this year prefaced by a somewhat longer summary of the Committee's major activities since June 1959*. Much time was given to consideration of possible changes in the university population during the 'sixties and 'seventies ; and, following the Chancellor of the Exchequer's authorization in January 1960 to discuss with the universities the practicability of providing $170,000-175,000$ places by the early 'seventies, the Committee asked the universities to consider what further expansion in student numbers they were prepared to contemplate by that date, together with their requirements for new accommodation. On the basis of subsequent discussions with the universities, the Committee has prepared a report for the Chancellor of the Exchequer. These discussions indicated that the existing universities, including the newly founded University of Sussex, could not of themselves alone provide a sufficient number of places, and that some new institutions were needed. The Committee therefore recommended to the Chancellor in March that immediate steps should be taken to encourage the establishment of new universities at Norwich and

- University Grants Committee. Returns from Universities and University Colleges in receipt of Treasury Grant, Academic Year 1958-1959. Pp. 58. (Cmnd. 1166.) (London : H.M. Stationery Office, 1960.) 4s. Bd. net.
York, and authority to initiate such foundations was given in April.

After consultation with the Committee of ViceChancellors and Principals, the Committee has advised that these new institutions, which are to be multi-faculty, should have powers from the start to grant both first and advanced degrees, to set their own entrance requirements and to devise their own curricula. It is proposed that the safeguards previously achieved by close association with an existing university institution should be secured for a period by means of an Academic Advisory Committee consisting of members from existing universities and, possibly, with lay representatives. Possible means of assisting St. David's College, Lampeter, were explored during the year ; a scheme has since been approved.

An independent sub-committee, with Sir William Hayter as chairman, was appointed to review developments in the universities in the field of Oriental, Slavonic, East European and African studies, consequent on the recommendations of the Scarbrough Commission in 1947, and to consider and advise on proposals for future developments.

An inquiry concluded during the year into the success or failure of students entering universities in October 1955 to study arts, pure science, technology, agriculture or forestry, showed that the proportion who left without success on account of academic failure was only 9.9 per cent, compared with 11.3 per cent in an earlier survey in 1952 . 